\title{
ПЕРСПЕКТИВЫ АТОМНОЙ ЭНЕРГЕТИКИ В ОБЕСПЕЧЕНИИ ЭНЕРГЕТИЧЕСКОЙ И ЭКОИОГИЧЕСКОЙ БЕЗОПАСНОСТИ РОССИИ
}

\author{
Р.М. Яковлев*, И.А. Обухова** \\ * Радиевый институт им. В.Г. Хлопина и ** Санкт-Петербургский государственный лесотехнический \\ университет им. С.М. Кирова, Санкт-Петербург, Россия \\ Эл.noчma:*Robertgood2019@gmail.com;**IObukhova@inbox.ru \\ Статья поступила в редакцию 30.11.2020; принята к печати 18.06.2021
}

ЯАерная энергетика крупных масштабов может обеспечить почти все энергопотребление мюбых видов, то есть энергетическүю безопасность не только России, но и всего человечества, но при этом созАवет цемый ряА острых проблем. При этом такой пүтъ Аһя России является приоритетным. Росатом строит многие ядерные рескторы не только у себя, но и за рубежом при условии поставки Аля них яАерного топиива (ЯТ) с послеАүющим возвратом в Россию отработанного ЯТ Аля переработки в үран-пиутониевое МОКС-топливо. В г. Железногорске поА Красноярском построена и Аействует первая очереАь комбината по переработке 2000 тонн отработанного Ят в ГоА. ГАавным стратегическим планом Росатома, который начаи осуществляться, является развития атомной энергетики с замыканием яАерного топливного цикла при использовании реакторов на быстрых нейтронах ААя произвоАства пАүтония, который может использоваться в яАерном оружии и наиболее опасен Аля биосферы. Аварии с выбросом высокой радиосктивноти, которые немьзя искиючить, становятся намного опаснее с пиутониевым топливом. Высокозवтратный атомный путь развития энергетики страны является опасным не только аля России.

Ключевые слова: атомные электростанции, замыкание топливного ичикла, отработанное ядерное топливо, реактор большой мошности канального типа, уран-плутониевый ядерный топливный изикл, торий-урановый ядерный топливный ичикл, нераспространение ядерного оружия, уран-плутониевое смешанное оксидное топливо, реактор на быстрых нейтронах, жидкосолевой реактор.

\section{PROSPECTS FOR NUCLEAR ENERGETICS IN SECURING THE ENERGY AND ENVIRONMENTAL SAFETY OF RUSSIA}

\author{
R.M. Yakovlev*, I.A. Obukhova** \\ *V.G. Khlopin Radium Institute and ${ }^{*}$ Saint-Petersburg State Forest Technical University \\ Email:*Robertgood2019@gmail.com;**IObukhova@inbox.ru
}

Large-scale nuclear energetics can satisfy demands for all kinds of energy, i.e. it can secure energy safety of Russia and the whole humankind; however, this is associated with a number of daunting problems. With that, this approach is a priority for Russia. The State Corporation RosAtom is involved in the development of nuclear reactors in Russia and abroad on the conditions that the reactors will be supplied with nuclear fuel from Russia and the spent fuel will be returned to Russia for conversion into mixed uranium and plutonium oxide (MOX) fuel. In the city Zheleznogorsk near Krasnoyarsk, the first production line of a plant for treating 2000 tons of spent nuclear fuel annually has been already launched. The principal strategic plan of RosAtom, which has been being realized currently, is to develop nuclear power production based on fuel recycling using fast neutron reactors for generation of plutonium, which may be used in nuclear weapons and is most hazardous for the biosphere. The possibility of accidents associated with radioactive discharges cannot be excluded, and the hazardousness of such accidents in increased by using plutoniumbased fuels. The nuclear power-based approach to energy production is costly but also dangerous not only for Russia.

Keywords: nuclear power plants, nuclear fuel recycling, spent nuclear fuel, channel-type reactor, uranium-plutonium fuel cycle, thoriumuranium fuel cycle, nuclear weapons nonproliferation, MOX fuel, fast neutrons reactor, molten salt reactor.

Список сокращений:
АЭ
атомная энергетика
АЭС
атомные электростанции
ГХК
Горно-химический комбинат (г. Железногорск)
ТВЭЛ
Тепловыделяющий элемент 
ТЭС

ВИЭ

ВПК

КИУМ

МАГАТЭ

MOKC

ОЯТ

PAO

РБМК тепловые электростанции

возобновляемые источники энергии (без гидроэнергетики и биотоплива)

военно-промышленный комплекс

коэффициент использования установленной мощности

Международное агентство по атомной энергии

уран-плутониевое оксидное топливо, полученное из ОЯТ (от англ. Mixed Oxide, MOX)

отработанное ядерное топливо

радиоактивные отходы

реактор большой мощности канального типа (Чернобыльский)

Статья посвящается доброй памяти председателя петербургского отделения Пагуошского движения проф. М.Б. Игнатьева, ушедшего из жизни в 2019 году.

\section{ВвеАение}

По словам академика А.П. Александрова, «ядерная энергетика крупных масштабов, обеспечивающая подавляющую часть энергопотребления всех видов, явится величайшим благом для человечества и разрешит целый ряд острых проблем» [1]. Эта цитата взята из изданного в 1977 году юбилейного сборника, авторский коллектив которого состоял из 90 ведущих представителей атомной науки и промышленности, включая 11 академиков РАН СССР и 6 главных организаторов промышленности. Но обернулась эта энергетика катастрофой. Через 9 лет на наиболее перспективном, по мнению авторов сборника, РБМК произошла крупнейшая в истории человечества техногенная авария с выбросом во внешнюю среду высокой радиоактивности и загрязнением ею значительной доли поверхности Земли. После этой катастрофы внимание общественности было привлечено ко многим другим авариям в атомной промышленности, и открылись серьезные проблемы атомной энергетики, которые делают ее распространение весьма опасным. Повторяемые руководителями атомного ведомства уверения в особой экологической чистоте и крайне низкой вероятности большой аварии звучат менее убедительно, чем заверения 44-летней давности. Ведь до аварий в Чернобыле и Фукусиме было далеко, а вера президенту АН СССР А.П. Александрову, трижды герою социалистического труда и члену ЦК КПСС, была велика. Атомная энергетика, производящая миллиарды кюри весьма опасных для биосферы и людей радиоактивных продуктов, в случае попадания части из них во внешнюю среду приводит к ее катастрофическому загрязнению и к сокращению площадей, пригодных для земледелия [9]. Напомним: при аварии на 4-м блоке Чернобыльской АЭС всего 5\% выброса накопленной в активной зоне реактора активности оказалось достаточно, чтобы сделать непригодными для проживания 7 тысяч кв. км, и 350 тысяч людей были отселены. Значительно большие площади с загрязнением более $15 \mathrm{Kи} / \mathrm{\kappa m}^{2}$ признаны опасными для здоровья и для производства с/х продуктов [29, 30]. Последствия же фукусимской аварии для экологии и биосферы явно недооцениваются. В нашей предыдущей публикации [36] на основании данных из статьи [20] был сделан вывод, что общий выброс радиоактивности в Японии от четырех реакторов, где расплавилось топливо, на порядок ниже, чем в Чернобыле. Но это, как выяснилось позже, не совсем так. Общее загрязнение непосредственно территории Японии действительно на порядок ниже. Но были большие выбросы в атмосферу в восточном направлении, один из которых, повернув к югу, чуть не накрыл Токио, а также происходило и происходит просачивание в океан воды, которой охлаждали и продолжают охлаждать разрушенные и разогреваемые остаточным тепловыделением активные зоны реакторов, загрязняя Тихий океан. Академик Е.П. Велихов в интервью для программы «Проект 2035»' отмечал: «Авария на этой электростанции спровоцировала самое масштабное в истории радиоактивное загрязнение природы». Радиоактивность от Фукусимы, Чернобыля и захоронения ядерных отходов влияет на окружающую среду, воздействует на почву и может привести к самым неожиданным последствиям. Предложения отказаться от атомной энергии в современном виде и перейти к более безопасной ториевой энергетике неоднократно публиковались [24, 31-33] и высказывались в Петербургском отделении Пагуошского комитета по нераспространению ядерного оружия, председателем которого был проф. М.Б. Игнатьев. Особое внимание при этом уделялось возможности того, что в рамках существующей уран-плутониевой энергетики может распространяться основная составляющая ядерного оружия - плутоний. Наибольшую опасность представляет не крупная авария на реакторе, а война с применением ядерного оружия [35-37].

\footnotetext{
' http://2035.media/2017/12/22/velikhov-interview/
} 


\section{ЯАерное оружие и его опссность Аля жизни на Земие}

Режим нераспространения не будет устойчивым, пока растет число государств, обладающих требующими самого деликатного обращения технологиями ядерного топливного цикла и способных произвести ядерное оружие при первой необходимости.

В США в министерстве обороны была подготовлена и издана комиссией по атомной энергии в 1962 году книга «The effects of nuclear weapons», в которой приведены данные о действии атомного оружия, полученные в результате теоретических исследований и практических испытаний, а также на основании изучения последствий взрывов атомных бомб в Хиросиме и Нагасаки. В 1965 году перевод с английского появился в СССР [6]. После ознакомления с этой книгой любой разумный человек поймет ужас ядерной войны. Напомним: при воздушном взрыве бомбы, эквивалентной 10 мегатоннам тринитротолуола, на расстоянии 9,4 км от эпицентра разрушаются здания с бетонными стенами и на расстоянии 13,9 км все многоквартирные кирпичные с несущими стенами ([6], табл. 12.21 на с. 621). Велика опасность от образующихся при взрыве радиоактивных продуктов. На с. 451-453 приведена уникальная информация о радиоактивном заражении на Маршалловых островах в результате испытательного взрыва «Браво», произведенного у атолла Бикини 1 марта 1954 года. Общая мощность взрыва соответствовала 15 мегатоннам. В результате взрыва возникло сильное заражение района вдоль направления ветра протяженностью более 530 км и шириной около 100 км. На полосе длиной 260 и шириной 50 км вдоль направления ветра измеренная за 96 часов доза превышала 700 рентген и была смертельно опасна. При другом взрыве неожиданно очень высокая доза была зарегистрирована на атолле Ронгелап. На северо-западной оконечности атолла в 160 км от эпицентра взрыва суммарная доза за 96 часов после начала выпадения радиоактивных продуктов составила 3300 рентген. Мы привели всего два эпизода из книги, в которой 680 страниц весьма интересного текста с многими фотоснимками (в том числе и многих японцев после Хиросимы), схемами и диаграммами, чтобы читатель проникся ужасом войны ядерной. Ведь не очень большой ядерный взрыв (1-2 мегатонны тротилового эквивалента) уничтожает большой город, например НьюЙорк или Петербург, а хвост радиоактивный убивает окрестности. В ядерной войне подвергаются смертельной опасности не только объекты бомбардировок.

В 1970-х и 1980-х годах в США под руководством К. Сагана [38] и в СССР под руководством акад. Н.Н. Моисеева $[2,15]$ были выполнены расчеты, которые показали, что помимо локального разрушения и высокого уровня радиоактивного загрязнения ядерная война между США и СССР приведет к гибели жизни на Земле. Мы приводим здесь довольно длинную цитату из работы [14], чтобы напомнить, насколько большую опасность заключает в себе ядерное оружие:

«Даже если в ядерной войне будет использовано всего лишь 100-150 мегатонн ядерного горючего, но оно будет распределено надлежащим образом по основным городам Европы, Азии и Америки, то эти города также сгорят в огненных вихрях. В результате образуются облака сажи такого размера, что “ядерная зима” все равно наступит. Только закончится она не через год, а через несколько месяцев. Но и это достаточный срок, чтобы покончить с жизнью Человека на Земле. А что такое 100-150 мегатонн? Это количество ядерного оружия немногим превышает то, которое носят на себе атомные подводные лодки. Такие числа дают представления о том, над краем какой бездны сейчас оказалось человечество. Результаты этих расчетов подтвердили гипотезу и дали первые количественные оценки эффекта ядерной зимы».

Атомные реакторы, устройства по обогащению урана его делящимся изотопом ураном-235, выделение плутония из облученного топлива напрямую перешли из ВПК и используются в мирной атомной энергетике. В любой стране, где появляется атомный реактор, а также специалисты, обученные ядерной физике и радиохимии в тех странах, которые для них реакторы построили, открывается возможность при использовании давно опубликованных технологий получить сначала ядерную взрывчатку и при ее наличии без особых проблем перейти к атомной бомбе. Это и произошло сначала в Израиле, а затем в ЮАР, Индии, Пакистане, а затем уже в КНДР при помощи специалистов из тех стран, которые создали ядерное оружие. И только лишь в ЮАР при смене политического режима отказались от атомного оружия и ликвидировали все военные ядерные разработки.

Прямое ядерное столкновение между Россией и США вместе со странами НАТО исключены ввиду неизбежного ответного удара, что означает применение большого количества ядерного оружия и гибель всего человечества. Но любой острый конфликт между государствами, создавшими у себя, несмотря на запреты, ядерное оружие, может явиться запуском большой ядерной войны с втягиванием в конфликт других государств, обладающих им. В этой войне не может быть не только победителей и побежденных, но даже нейтральных. Причем роковым может оказаться даже и сравнительно небольшой ядерный конфликт. Значит, приобщение каждой новой страны к ядерным арсеналам увеличивает угрозу не только для ее потенциальных противников, но и для всего мира. Сейчас значительно расширяется география размещения атомных станций по всему миру, и многие реакторы строит Россия. Расширение географии увеличивает опасность создания ядерного оружия и его примене- 
ния со стороны тех стран, руководители которых могут попытаться использовать его для уничтожения ненавистного противника.

При поставке же МОКС-топлива в зарубежные реакторы извлечь из него несколько килограмм плутония для ядерного заряда не представит особых проблем. Взрывное устройство с высоким КПД создать сложно, но если из 10 кг во время взрыва разделится хотя бы 1 г, то это эквивалентно взрыву 18 тонн тринитротолуола, а распылившийся остальной плутоний (9999 г) нанесет непоправимый урон стране, где произошел взрыв. Опасность, которую может принести простое распыление только одного топливного элемента МОКС-топлива, содержащего всего 200 г плутония, было исследовано в работе [11]. В статье [36] мы привели итоговую таблицу по данным из указанной работы, чтобы показать, какую высокую опасность здоровью тысяч жителей несет распыление в городе свежего МОКС-топлива от всего лишь одного ТВЭЛа: число избыточных смертей от рака превысит 300.

\section{Атомная энергетика России: ее статус и перспективы}

«Светлое будущее наступит не от бельх ночей, а от атомных станицйџ.

E.A. Решетников, вице-президент 3 АО «Атомстрой проект», 2008 год [19]

Из-за глобального кризиса и сокращения многих энергоемких отраслей промышленного производства нужда в росте внутреннего потребления энергии в Российской Федерации отсутствует [17, 39]. Почти половина добываемых ресурсов уходит на экспорт, и, согласно новой стратегии развития энергетики до 2035 года, потребление ресурсов в РФ к 2035 году уменьшится на 2,5\%, а вот экспорт возрастет на $15,2 \%{ }^{2}$. Экономика страны остается сырьевой, и это понятно, поскольку, как отмечено в стратегии, доля топливно-энергетического комплекса в структуре доходов федерального бюджета - около 40\%, а в российском экспорте (в стоимостном выражении) более половины, при том, что доля занятых в отраслях топливно-энергетического комплекса составляет менее $4 \%$ общей численности населения, занятого в экономике. То есть продажа невосполнимого природного богатства России во много раз выгоднее любой другой деятельности. Дополнительные установленные мощности, в том числе и электрические, в такой экономике не требуются.

Посмотрим по отчетам Министерства энергетики ${ }^{3}$, в какой мере действующие электростанции обеспечива-

\footnotetext{
Энергетическая стратегия Российской Федерации на период до 2035 года. http://static.government.ru/media/files/w4sigFOiDjGVDYT4 IgsApssm6mZRb7wx.pdf

https://minenergo.gov.ru/node/7573
}

ют сейчас Россию электроэнергией. На конец 2020 года общая установленная мощность электростанций ЕЭС России составила 245313,25 МВт. Выработка электроэнергии электростанциями ЕЭС России в 2020 году составила 1047,03 млрд кВт·ч. Потребление электроэнергии в 2020 году составило 1033,72 млрд кВт·ч. Относительная выработка электроэнергии составила: ТЭС - 59,3\%; АЭС $-20,6 \% ;$ ГЭС $-20,1 \%{ }^{4}$.

Видно, что основную роль в электроснабжении играют ТЭС. Эти же станции вносят весьма существенный вклад в теплоснабжение. По итогам 2016 года объем производства тепловой энергии в РФ составил 1284 млн Гкал, причем 46,5\% этого объема было произведено котельными, и 45,9\% произвели ТЭС. Таким образом на ТЭС произведено 589,36 млн Гкал или 683,6 млрд кВт·час $\left(1\right.$ ккал $=1,163 \times 10^{-3}$ кВт·ч), что даже больше произведенной на этих станциях электрической энергии (621 млрд кВт·ч). В нашей северной стране было бы очень неосмотрительно заменять ТЭС атомными или ветровыми станциями из-за того, что, хотя тепловые производят парниковые газы, они производят тепло, в отличие от гидростанций и атомных и ветровых станций. В стратегии развития их доля (60\%) в производстве электроэнергии сохраняется. Новый министр энергетики Н.Г. Шульгинов в интервью журналу «Энергетическая политика» 14 мая 2021 года сказал, что не надо спешить расставаться с углеводородами, надо наравне с традиционными видами энергетики развивать ВИЭ, и что надо учесть опыт прошедшей зимы, когда на фоне сильных морозов возник всплеск спроса на традиционные виды топлива. Рассчитывать только на солнце и ветер без новых развитых систем накопления энергии не стоит, и поэтому необходимо постоянно содержать резерв традиционной генерации и запасы традиционных видов топлива 5 .

В отчете Министерства энергетики за 2020 год приведена следующая информация о загрузке электростанций разного типа. Число часов использования установленной мощности электростанций в целом по ЕЭС России в 2020 году составило 4238 часов, или 48,25\% календарного времени (коэффициент использования установленной мощности - КИУМ). При этом число часов использования установленной мощности без учета электростанций промышленных предприятий составляет (в скобках - КИУМ): у тепловых электростанций - 3361 (41,34\%); у атомных электростанций $-7156(81,47 \%) ;$ у гидроэлектростанций -4157 (47,33\%); у ветровых электростанций - 2413 (27,47\%); у солнечных электростанций - 1324 часов (15,08\%). Видно, что ТЭС и ГЭС работали с большой недогрузкой. Резервы мощности электрических станций на час прохождения годового максимума потребления

\footnotetext{
4 https://minenergo.gov.ru/activity/statistic

https://minenergo.gov.ru/node/20686
} 
мощности ЕЭС России также велики и составили в 2020 году 45,7 ГВт.

При столь большом резерве неиспользованной традиционной энергии увеличивать число электростанций не имеет смысла, и в новой стратегии до 2035 года установленная мощность практически сохраняется. Решение задач электроэнергетики потребует поддержания установленной мощности электростанций в энергосистемах в период до 2024 года на уровне 254 ГВт, а в период до 2035 года - в диапазоне 251264 ГВТ.

В атомной энергетике установленная мощность всех АЭС в 2018 году составляла 30,3 ГВт. Выработка электрической энергии атомными электростанциями в период с 2008 по 2018 год увеличилась на 25\%. Начиная с 2008 года введены в эксплуатацию энергоблоки № 2, 3 и 4 Ростовской атомной электростанции, энергоблок № 4 Калининской атомной электростанции, энергоблок № 4 Белоярской атомной электростанции, энергоблоки № 1 и 2 Нововоронежской атомной электростанции-2 и энергоблок № 1 Ленинградской атомной электростанции-2. Продолжалось строительство других энергоблоков атомных электростанций с реакторами большой мощности, в том числе энергоблока № 2 Ленинградской атомной электростанции-2 и энергоблоков № 1 и 2 Курской атомной электростанции-2.

Установленная мощность АЭС до 2035 года останется практически той же самой. Будут сооружены новые реакторы общей мощностью 13 ГВт, но за это же время будут выведены из эксплуатации энергоблоки общей мощностью 12,9 ГВт, и доля 20\% в производстве электроэнергии сохранится ${ }^{6}$. В стратегии развития отмечено отдельно, что на АЭС России доля блоков 3-го поколения, которая в 2018 году составляла 13\%, к 2024 году составит 26\%; к 2035 году - 40\%. Это, безусловно, сделает АЭ более безопасной, особенно при снятии с эксплуатации блоков РБМК Чернобыльского типа, проектный срок эксплуатации которых давно истек. Несомненно, важным и полезным для страны явится строительство нескольких больших атомных ледоколов.

Отметим также, что запасы (разведанные и извлекаемые) урана России, приведенные в таблице «В» на c. 19 Белой книги ядерной энергетики [3], составляют 9000 ГВт×год, и при установленной мощности 30 ГВт этих запасов хватит при спокойном дожигании в достаточно безопасных тепловых легководных реакторах третьего и затем еще более безопасных реакторах следующих поколений на 300 лет, а если установленная мощность возрастет до 45 ГВт, то разведанных на 2001 год запасов урана хватит на 200 лет. Если учесть, что после 2001 года в самой России (в Забайкалье) и

http://www.innov-rosatom.ru/upload/medialibrary/90a/2.\%20\%D0\%94 $\% \mathrm{D} 0 \% \mathrm{BE} \% \mathrm{D} 0 \% \mathrm{BA} \% \mathrm{D} 0 \% \mathrm{BB} \% \mathrm{D} 0 \% \mathrm{~B} 0 \% \mathrm{D} 0 \% \mathrm{~B} 4 \% 20 \% \mathrm{D} 0 \% 93 \% \mathrm{D} 0 \%$ BE\%D0\%BB\%D0\%BE\%D0\%B2\%D0\%B8\%D0\%BD.pdf
Казахстане разведаны новые месторождения урана, то число лет можно удвоить или утроить.

Необходимость в значительном увеличении парка реакторов не предвидится в нашей стране и в последующие годы. К 2050 году Росатом планирует повысить установленную мощность всего на 8 ГВт, что увеличит долю в генерации электроэнергии от 20 до 22\%. В России не требуется в ближайшие два десятилетия увеличение установленной мощности атомных станций из-за отсутствия потребности и большой недозагруженности гидро- и теплоэлектростанций.

Но зато Росатом строит много реакторов в других государствах. С 2008 года Росатом принимает активное участие в строительстве атомных электростанций за рубежом (энергоблоки № 1 и 2 атомной электростанции Куданкулам в Республике Индии, энергоблоки № 3 и 4 атомной электростанции Тяньвань в Китайской Народной Республике), а сейчас еще и подписаны соглашения о строительстве большого числа иностранных реакторов. Россия сейчас заключила контракты на сооружение 36 атомных реакторов за рубежом и сооружает реакторы в Турции, Иране, Китае, Египте, Индии, Вьетнаме, Бангладеш, Финляндии, Венгрии, Беларуси, Узбекистане. В 2018 году АО «Концерн Росэнергоатом» выполнил работы по контракту на оказание услуг по оценке и развитию ядерной инфраструктуры Республики Замбии; подписан трехлетний контракт на оказание услуг по развитию ядерной инфраструктуры Боливии.

Как отмечено в предыдущем разделе, в любой стране, где появляются атомные реакторы, появляется и плутоний. Технологии выделения плутония из ОЯТ давно опубликованы, и извлечь его в нужном количестве для взрывного устройства всегда возможно. То есть, когда появляется в стране ядерный реактор, открывается возможность получить основную составляющую атомной бомбы - плутоний. Мы не будем далее обсуждать эту вполне очевидную опасность. Пускай этим занимаются эксперты из МАГАТЭ, находящиеся в Вене, столице государства, где нет ни одного реактора, но считающие большим благом для человечества распространение, при содействии МАГАТЭ, мирной атомной энергии по всей планете.

Наши атомщики при зарубежном строительстве оказываются занятыми. Все было бы хорошо, если бы только не собирались они по договорам привозить назад в Россию, как и во времена СССР из стран СЭВ, радиоактивное отработанное ядерное топливо. Для жителей страны и ее биосферы сооружение зарубежных реакторов и снабжение их ядерным топливом не принесет вреда без возврата ОЯТ, правда, запасы урана для нас становятся меньше, но это как с газом-нефтью.

Строительство АЭС за рубежом не является чем-то исключительным. При согласовании с МАГАТЭ строили за рубежом реакторы компании разных стран (из 
США, Англии, Франции, Германии, Японии, Южной Кореи и Китая). В странах Восточной Европы с 1960 по 1986 год при помощи СССР были построены АЭС в основном с реакторами типа ВВЭР-440 для многих стран СЭВ. Ядерное топливо для них поставлялось из СССР, и затем ОЯТ после нескольких лет выдержки возвращалось снова в СССР для переработки на предприятии «Маяк», где оно частично использовалось для изготовления ядерного топлива реакторов РБМК. В Англию и Францию также привозилось на комбинаты для переработки ОЯТ от реакторов, которые были построены английскими и французскими компаниями.

В те времена атомная энергетика была на подъеме, и предполагалось, что к началу нашего века будет построено несколько тысяч атомных реакторов, для которых резервы делящегося изотопа урана-235 (относительная доля его в уране 0,7) очень быстро будут исчерпаны. Выход из этой ситуации казался очевидным и простым, поскольку уже в 1960-х годах были сделаны теоретические и экспериментальные разработки, из которых следовало, что можно поделить весь уран, если превратить неделящийся изотоп уран-238 в плутоний-239. При сжигании всего урана ресурсы возрастают в 150 раз. Тогда в России при установленной мощности не 45 ГВт, а 1200 ГВт это означает замену не только других источников электрической энергии, но и всех источников потребляемой энергии на атомные. Действительно, общая энергия, полученная от АЭС при установленной мощности 1200 ГВт (КИУМ =0,7), за год составит 7358 млрд кВт·ч. Это величина всей употребленной в РФ энергии в 2001 году. То есть остальные источники энергии не нужны, и можно продавать на экспорт не половину добытых в стране газа, нефти и угля, а все. Эта весьма завлекательная для руководства страны информация приведена в той же таблице из Белой книги [3], на которую мы ссылались выше. Там же отмечено, что запасов урана хватит при увеличенной мощности на 1300 лет. Но для этого нужно замыкать ядерный топливный цикл, перерабатывать все ядерное топливо после облучения и строить реакторы на быстрых нейтронах, в которых рождается больше нейтронов и коэффициент воспроизводства топлива для которых значительно выше, чем для легководных реакторов.

Для обеспечения автономной работы только одного реактора на быстрых нейтронах электрической мощности 1 ГВт требуется не менее 20 тонн плутония с учетом, кроме необходимого количества для загрузки активной зоны реактора (выгорает не более 10\%), еще и последующей выдержки, переработки и изготовления новых топливных элементов. Автономный режим с переработкой топлива с плутонием необходим, чтобы избежать перевозки высокорадиоактивного топлива на большие расстояния. При запуске одного нового реактора на быстрых нейтронах необходимый плутоний предполагалось получать из отработанного топлива реакторов на тепловых нейтронах. В 1 тонне облученного урана в топливе содержится 10 кг плутония, в нем делящихся изотопов плутония-239-5,53 кг и плутония-241-1,47 кг. Чтобы получить 20 тонн плутония, потребуется переработать более 2800 тонн ОЯТ, которые образуются в 28,5 активных зонах реактора ВВЭР после трех лет облучения в них топлива (в 79,6 тоннах ОЯТ реактора ВВЭР-1000 после трех лет облучения содержится 700 кг плутония, в котором 500 кг делящихся изотопов плутония). До 2800 тонн ОЯТ содержится в 40 активных зонах реактора после облучения каждой по три года. ОЯТ становится ценным сырьем для получения плутония быстрых реакторов, которых предполагали поставить по свету несколько тысяч, причем первые несколько сотен загрузить плутонием из ОЯТ тепловых реакторов. Если строить и запускать в автономном режиме быстрые реакторы, тогда и только тогда ОЯТ легководных реакторов становится не опасными отходами, а ценным сырьем, которое надо перерабатывать.

Но интенсивного развития атомной энергетики, как предполагалось в прежнем стратегическом плане 2008 года и отмечено в начале этого раздела, не произошло. Построен только один реактор БН-800 на быстрых нейтронах, в новой стратегии развития энергетики не намечено появление большого числа их в ближайшие десятилетия. Извлеченный плутоний становится очень опасным продуктом, требующим особых условий хранения и охраны. Использовать его в тепловых реакторах довольно сложно, поскольку они не рассчитаны на загрузку плутонием. Только в небольшой части тепловых реакторов его можно применить, да и то только при загрузке не более чем третьей части ТВЭЛов. Наработка его без реальных быстрых реакторов является не просто бесполезной, но и очень опасной затеей, однако не для Росатома. И вот почему. Только необходимостью наработки плутония из ОЯТ для большого числа быстрых реакторов, в которые его должны загрузить, можно обосновать запланированное во многих договорах Росатома возвращение в Россию очень радиоактивного материала, каковым является ОЯТ, и, тем более, его переработку с целью замыкания непонятно чего и в чем.

Опасность для России и других стран возникает безо всяких злоумышленников, причем весьма большая, из-за огромного количества радиоактивности, которое содержится в ОЯТ от реакторов, возводимых Росатомом на территории иностранных государств, и будет перевозиться в хранилище в Железногорск в количестве 80 тонн от каждого реактора после трех лет облучения в реакторе. Дальнейшая информация взята из справочника [7] для реактора ВВЭР-1000 при загрузке в него 79,6 тонны оксида урана с 4,4\% урана-235. Ра- 
диоактивность одной тонны топлива после облучения составляет сразу после его останова $9,61 \times 10^{18}$ Бк, это 260 млн Ки в одной тонне, и после трех лет хранения в приреакторной зоне радиоактивность снижается в 230 раз и составляет $4,14 \times 10^{16}$ Бк $=1,12$ млн Ки. Далее снижение активности происходит медленно, только через 10 лет ее становится в два раза меньше. После трех лет ОЯТ можно перевозить в специальных контейнерах. Это обычно так и делают. Поскольку при задержке распадается делящийся изотоп плутоний-241. В 79,6 тонны активность топлива составляет 80 млн Ки. Это трехлетняя наработка, и в год от 36 реакторов будет нарабатываться в среднем 960 тонн высокоактивных радиоактивных продуктов с общей активностью 960 млн Ки. Если бы эти тонны и Кюри оставались в странах, где будут установлены реакторы, то все было бы нормально. Но, насколько нам известно, во многих договорах поставлено условие как поставки ядерного топлива для сооружаемых Росатомом реакторов, так и возвращения ОЯТ после некоторой выдержки. Печально, если это произойдет, и лучше бы отказаться от этого условия. Но в нашей стране очень давно прорабатывается и уже начал осуществляться опасный вариант с замыканием ядерного топливного цикла. Именно этим и оправдывают руководители Росатома возвращение в страну ОЯТ зарубежных реакторов, называя его ценным сырьем для большой ядерной энергетики с замыканием ядерного топливного цикла, с многими быстрыми реакторами и переработкой всего ядерного топлива. Представители Росатома пытаются убедить руководителей страны и общественность в благотворности и полной безопасности перехода всей страны на очень безопасную и чистую при малом количестве отходов ядерную энергетику, не производящую парниковых газов, причем при замене атомной энергией других энергетических мощностей можно сократить потребление углеводородов и угля в России и увеличить их экспорт. На колоссальное количество необходимой переработки очень радиоактивных продуктов, которые при этом возникают, и на опасность плутония, являющегося основным сырьевым продуктом в замыкании ядерного топливного цикла, внимание не заостряется.

Поскольку в запуске новых энергетических мощностей, в том числе и атомных, в РФ нет потребности, и атомная энергетика вполне обеспечена сырьем на столетия при существующем числе атомных реакторов, и рост их числа после 2050 года может быть незначительны, нет никаких объективных оснований увеличивать многократно ресурсы урана и для этого запускать программу замыкания ядерного топливного цикла для сжигания всего урана через плутоний.

Тем не менее, программа запущена, и для ее осуществления выделено значительное финансирование. Недалеко от Красноярска на ГХК уже осуществляется переработка очень радиоактивного ядерного топлива с высоким содержанием плутония реактора БН-800 и изготовление из него МОКС-топлива, которое перевозится обратно в г. Заречный для повторного использования в том же реакторе. На ГХК создано грандиозное сухое хранилище для приемки отработанного ядерного топлива своих реакторов и иностранных, которые Росатом построил и собирается строить за рубежом с целью последующей переработки ОЯТ от своих и зарубежных легководных реакторов для получения уран-плутониевого оксидного МОКС-топлива.

Атомная энергетика с замыканием уран-плутониевого цикла считается приоритетной. На Белоярской АЭС кроме действующего реактора БН-800 предполагается установить еще два реактора на быстрых нейтронах БН-1200 с натриевым охлаждением.

Также предполагается разработать и изготовить опытные образцы реакторов на быстрых нейтронах с охлаждением расплавом свинца (БРЕСТ-300) и свинца-висмута (СВБР). Научным руководителем этого направления, названного «Прорывом»7 , является бывший глава атомного ведомства Е.О. Адамов. Работы в этом направлении вряд ли приведут к успеху, поскольку свинец растворяет любой металл (именно поэтому он и используется при сварке), а висмут и основной изотоп свинца $\mathrm{Pb}-208$, при захвате нейтрона становясь Вi-209, являются источником, проникающим через любые щели радиоактивного полония-210. Поэтому казавшиеся сначала весьма перспективными свинцово-висмутовые реакторы, разработанные для подводных лодок, после нескольких аварий были отменены.

Тем не менее, на территории Сибирского химического комбината при осуществлении программы «Прорыв» возводится опытно-демонстрационный энергетический комплекс (ОДЭК), состоящий из энергоблока с реактором БРЕСТ-ОД-300 со свинцовым теплоносителем и замыкающего ядерный топливный цикл пристанционного завода, который включает в себя модуль переработки облученного смешанного уран-плутониевого нитридного топлива и модуль фабрикации/рефабрикации для изготовления стартовых ТВЭЛов из привозных материалов, а впоследствии ТВЭЛов из переработанного облученного ядерного топлива.

На проект «Прорыв» выделены весьма значительные средства. Проект открывается такими словами: «Реализуемый Госкорпорацией Росатом проект "Прорыв" нацелен на достижение нового качества ядерной энергетики, разработку, создание и промышленную реализацию замкнутого ядерного топливного цикла (ЗЯТЦ) на базе реакторов на быстрых нейтронах, развивающих крупномасштабную ядерную энергетику. В реализации проекта участвуют более 30 организаций».

Проект «Прорыв» http://proryv2020.ru/o-proekte/ 
Как и 44 года назад, декларируется и утверждается руководителями атомного ведомства, а за ними руководством государства, что к жителям России и тех стран, где Росатом сооружает реакторы за счет России, на долгий срок (при замыкании затем уран-плутониевого ядерного цикла - на многие тысячелетия) придет самая безопасная, чистая и дешевая энергия.

До обсуждения особой опасности, которую несет в себе плутоний, отметим весьма важную и необходимую особенность процесса замыкания ядерного топливного цикла: это необходимость перевода ОЯТ в жидкое состояние и последующей переработки с целью извлечения нужных продуктов. При этом миллион Кюри оставшихся радиоактивных продуктов деления в 1 тонне ОЯТ после трех лет хранения рассредоточиваются от первичного объема $0,1 \mathrm{~m}^{3}$ к следующим объемам: высокоактивные $-45 \mathrm{~m}^{3}$, среднеактивные - $200 \mathrm{M}^{3}$, низкоактивные - $2000 \mathrm{M}^{3}$, с общей активностью 1 миллион Ки. С учетом первоначального объема отработавшего топлива в $0,1 \mathrm{M}^{3}$ на тонну процесс «переработки» увеличивает объем только высокоактивных отходов в 450 раз. Понятно, что при таком увеличении объемов изолировать их значительно сложнее, чем ОЯТ в контейнере. Средне- и низкоактивные радиоактивные отходы в процессе переработки топлива сбрасывались в США, Англии и Франции в море-океан, загрязняя биосферу Земли, а в России сбрасывались и до сих пор сбрасываются в оз. Карачай и в систему р. Теча.

А теперь перейдем к элементу, ради которого и осуществляется переработка топлива, - к плутонию, наиболее опасному для биосферы, в первую очередь для людей. Попадая в организм человека, плутоний становится постоянным источником альфа-излучения и вызывает костные опухоли, рак печени и лейкемию и таким образом является опасным канцерогеном [22]. Как отмечено [4, 5], плутоний, попав в организм, накапливается в костях и печени. Особенно хорошо он удерживается в костях и практически не удаляется и поэтому принадлежит к разряду наиболее токсичных веществ. Попадание 100 мкг в легкие гарантирует развитие рака легких, а размещение всего 1,4 мкг в костях может привести к раку костной ткани. Плутоний опасен при попадании во внешнюю среду и для других организмов, накапливаясь в них. Так, для водорослей коэффициент накопления составляет от 1000 до 9000 , для планктона - 2300, для желудка рыб - 5900. Наземные растения усваивают плутоний через корневую систему и накапливают до $0,01 \%$ к своей массе. Это означает, что в 1 кг картофеля или моркови может оказаться 10 мг плутония.

Атомная энергетика с уран-плутониевым твердым топливом, в котором накапливается колоссальная радиоактивность и которое предполагается все пере- рабатывать, производя затем МОКС-топливо, является весьма опасной для экологии даже без крупных аварий, которые никак нельзя исключить и которые все-таки происходят, вопреки уверениям в их невозможности, поступающих от руководителей атомного ведомства и от части ученых-атомщиков. Вероятность таких аварий значительно увеличивается при росте в мире террористической активности и возникающей возможности удара неядерным оружием по АЭС или хранилищу с ОЯТ. Последствия катастрофичны. Особенно высокая опасность развития атомной энергетики для человечества возникает при замыкании ядерного топливного цикла с реакторами на быстрых нейтронах и с необходимой переработкой ядерного топлива, содержащего высокую концентрацию плутония, часть которого неизбежно попадет в биосферу. В недавней публикации группы ученых во главе с акад. Е.П. Велиховым ${ }^{8}$ отмечено, что даже при весьма низком (и вряд ли достижимом) уровне потерь при переработке ОЯТ 0,1\% произойдет следующее: «В безвозвратные отходы будут поступать не только нестабильные продукты деления, но и тяжелье изотопы топливного иикла-уран, плутоний и др. За 100 лет работы предприятий по переработке ОЯТ ВВЭР в безвозвратных потерях будет накоплено около 10\% плутония, выделяемого при годовой переработке. В ОЯТ ВВЭР содержится всего около 1,2\% плутония. В том случае, когда переработке будет подвергнуто ОЯТ из активной зоны быстрых реакторов, в котором содержание плутония около $15 \%$, количество плутония в безвозвратных потерях за время работы реактора будет составлять более $150 \%$ от его количества, выделенного при годовой переработке. По мере работь ядерной энергетической системы только за счет безвозвратных потерь будут вне контроля накоплены тонны плутония и большое количество радиоактивных изотопов». Как отмечают авторы, уже при переработке топлива существующих легководных реакторов возникает тревожная для экологии ситуация: только два изотопа - Cs-137 и Sr-90 - обеспечат возрастание радиационного фона, по сравнению с создаваемым природным ураном, почти в 300 раз. А в случае плутония при многократной переработке топлива быстрых реакторов опасность для экологии и людей многократно возрастает.

Нужно учесть еще и следующее. Состав плутония в активной зоне реактора после нескольких загрузок уже не годен, поскольку в нем возникают неделящиеся четные изотопы плутония. Его надо обогащать или оружейным плутонием из запасов, или плутонием из зоны воспроизводства, где имеется обедненный уран-238, в котором будет образовываться плутоний-239, который отдельно из нескольких тонн урана- 238 следует извлечь, добавляя в топливо активной зоны. Для замыкания ядерного ци-

8 http://vant.iterru.ru/vant_2021_1/1.pdf 
кла с вовлечением всего урана зона воспроизводства совершенно необходима. Поэтому в зоне воспроизводства «мирных» быстрых реакторов будет происходить весьма эффективная наработка плутония оружейного качества (обогащение по изотопу ${ }^{239} \mathrm{Pu}$ до 93,5\%) с его раздельным выделением. Чтобы такой плутоний не уходил на изготовление оружия, за всеми реакторами на быстрых нейтронах необходимо установить строгий международный контроль, который не всегда эффективен.

Ставка на атомную энергетику как на основной источник энергии, особенно в варианте замыкания энергетического цикла с быстрыми реакторами и необходимой переработкой топлива с высоким содержанием плутония при каждом из них, является опасной для всей биосферы, а особенно для той страны, где эта переработка будет осуществляться, поскольку неизбежны потери при переработке, а исключить возможность как аварий, как и терактов можно только на бумаге.

Вариант значительно более безопасного развития атомной энергетики с использованием уран-ториевого топливного цикла с жидкосолевыми реакторами, который рассмотрен в ряде публикаций [10, 31-33], не удалось осуществить, поскольку средств на него творческий коллектив получить не смог. Безопасность такого типа реактора для внешней среды обусловлена тем, что в случае жидкого топлива при медленной циркуляции топлива в пределах активной зоны самого реактора из него будут удаляться все летучие продукты. Поэтому, даже если в реактор попадет бомба или снаряд, из топлива во внешнюю среду почти ничего не уйдет. Это во-первых. А во-вторых, в любых менее критичных ситуациях топливо может быть слито частично или полностью и рассредоточено по емкостям, содержащим поглощающие нейтроны вещества, например бор или кадмий, что полностью исключит возможность ядерного взрыва. В-третьих, отсутствие в топливе плутония и трансурановых элементов делает реактор такого типа более безопасным для экологии и создает меньше проблем для окончательного захоронения топлива. Более подробную информацию о уран-ториевых ЖСР и схему реактора небольшой мощности можно найти в статье [31].

От неосуществленных возможностей возвращаемся к действительности.

В России атомная энергетика остается ведущей отраслью при высоком бюджетном финансировании, в том числе и строительства реакторов за рубежом, несмотря на:

1) проблему нераспространения ядерного оружия;

2) исключительно высокий уровень опасности для биосферы при крупных авариях с разрушением ак- тивной зоны реактора или хранилища ОЯТ, особенно с МОКС-топливом;

3) проблему с накоплением огромного количества очень радиоактивных продуктов, которые хранить надо, охлаждая многие сотни лет, а переработка опасна для биосферы в связи с неминуемыми потерями многократно увеличенных объемов радиоактивных продуктов 9 ;

4) дороговизну (больше 7 млрд долларов за ГВт установленной мощности АЭС) и высокие расходы на хранение ОЯТ и РАО, что приводит к высокой себестоимость получаемой электроэнергии по сравнению с другими источниками (мы покажем это в следующем разделе), а также

5) нерешенные проблемы при снятии с эксплуатации, реабилитации территории и захоронения радиоактивных отходов.

Сейчас необходимость интенсивного развития атомной энергетики руководители атомного ведомства и заинтересованные в продолжении финансирования сотрудники обосновывают следующими аргументами. Во-первых (как 50 лет назад), это ограниченность и сравнительно быстрое исчерпание запасов нефти и газа в мире и высокое загрязнение биосферы при сжигании угля. Но сейчас этот аргумент звучит странно. Исчерпание природных ресурсов и дефицит энергии не угрожает человечеству. Запасы нефти и газа с учетом колоссальных резервов, находящихся в шельфовой зоне и особенно в сланцевых породах, весьма велики. Этих запасов хватит более чем на 2000 лет. Интересно, что и самих запасов природной нефти может быть значительно больше, если справедлива гипотеза о том, что значительная часть нефти (если не основная) имеет неорганическую природу и непрерывно возникает от выходящего из центра земли водорода при прохождении его через углеродсодержащие породы. Да и сам водород при его улавливании может использоваться как самое экологичное топливо. Это что касается топливной составляющей мировой энергетики. Если же добавить к топливной составляющей уже освоенную во многих странах энергию возобновляемых источников, то энергетическая безопасность человечества с лихвой обеспечена без уран-плутониевой атомной энергетики, весьма опасной для людей и биосферы. Поэтому многократно повторяемые руководителями Росатома заявления о безальтернативности атомной энергетики для обеспечения энергетической безопасности страны и человечества звучат все менее убедительно, особенно при учете альтернативных источников энергии.

Главную опасность для человечества представляет не недостаток энергообеспечения, а катастрофическое загрязнение внешней среды и сокращение

http://www.proatom.ru/modules.php?name=News\&file=print\&sid=7480 
площадей, пригодных для земледелия, в результате интенсивной индустриализации, в которой активную роль играет и атомная энергетика. Этот фактор может привести к сокращению численности населения до 500 млн к 2075 году и последующему медленному восстановлению погубленной цивилизацией природы и увеличением населения Земли до той оптимальной величины 1,4-1-1,7 млрд, которую может выдержать природа Земли, не разрушаясь в случае бережного к ней отношения $[8,13,21,23,25,26]$.

Поэтому первый аргумент, обосновывающий необходимость развития опасной атомной энергетики из-за истощения природных ресурсов и якобы из-за отсутствия других безопасных, надежных источников энергии, а также из-за предсказываемого сокращения численности населения, оказывается несостоятельным.

Спасительная ситуация для обоснования развития атомной энергетики возникла при развернувшейся борьбе с потеплением. Вторым и главным сейчас аргументом, обосновывающим необходимость строить много АЭС и развивать атомную энергетику, стало утверждение, что только эта энергетика спасет человечество от катастрофического потепления, обусловленного сжиганием слишком большого количества органического топлива. Да, действительно, атомная энергетика не производит парниковых газов. Заменить энергетику, основанную на сжигании органического топлива, атомной энергией предлагается не только в производстве электроэнергии, но и для транспорта, делая его электрическим, а также производя на АЭС водород в замену органики. Этот аргумент находит поддержку у растущего числа борцов с потеплением. Ввиду его важности для обоснования необходимости и широкого внедрения атомной энергетики оценим степень его обоснованности.

Академик Р.И. Нигматуллин, научный руководитель Института океанологии РАН им. П.П. Ширшова, на основании исследования предыдущих эпох изменения уровня океана показал, что основной причиной этого изменения уровня океана является Солнце, количество тепла от которого периодически меняется, приводя к изменению температуры на поверхности Земли, меняя соотношение воды в ледниках и в океане, и соответственно к изменению его уровня [18]. Содержание же $\mathrm{CO}_{2}$ в атмосфере напрямую связано с температурой воды в мировом океане, поскольку его находится в 100 раз больше, чем в воздухе, а половина растворена в воде в количестве, определяемом температурой воды. Сейчас уровень мирового океана незначительно увеличивается в связи с большей активностью Солнца и общим потеплением, приводящим к выделению углекислого газа из морской воды. Деятельность же человека по сравнению с этим процессом мало изменяет равновесное содержание этого газа в атмосфере. Сейчас активность процессов на Солнце начинает уменьшаться и, если будет сжигаться даже значительно больше органического топлива, то это не приведет к компенсации наметившегося похолодания, близкого к ледниковому периоду.

Такой же точки зрения придерживался и один из ведущих специалистов в области геофизики А.П. Капица. В интервью Дж. Молдованову ${ }^{10}$ он заявлял: «Уже много лет бывший президент Академии наук США Фредерик Зейтц (Seitz) обращал внимание на то, что все теории глобального потепления и озоновых дыр притянуты за уши и не отвечают действительности, что это - антинаучные теории. 17 тысяч американских ученых подписали петицию. Они согласны с Зейтцем и считают, что соглашение и стоящие за ним тенденции - подлинная угроза человечеству и тяжелый удар по его будущему».

Проф. А. Городницкий в статье «Конец мифа о глобальном потеплении» пишет: «Британские специалисты пришли к выводу, что уже через 10-15 лет на нашей планете наступит новое глобальное похолодание. Свои выводы ученые сделали на основе математической модели процессов, которые сегодня происходят на Солнце» ${ }^{11}$.

Анализ ситуации с потеплением был проведен в ряде работ $[27,28]$ сотрудников Арктического и Антарктического НИИ Росгидромета под руководством член-корр. РАН И.Е. Фролова. В этих работах были рассмотрены характерные особенности изменений климата Арктики и некоторых других регионов Земли с масштабами от десятилетий до столетий. Данные наблюдений позволили выявить полициклический характер климатических изменений, произошедших с конца XIX до начала XXI века. В Арктике наибольшую амплитуду имели 60-летние циклы, с которыми связано чередование теплых и холодных эпох. Аналогичные циклы обнаружены и в других регионах планеты. Возможной их причиной являются изменения полной энергии, поступающей к Земле от Солнца, включая энергию солнечной активности. На основе выполненной учеными реконструкции изменений этой энергии, а также фактических и восстановленных данных о температуре воздуха в Арктике и в Северном полушарии показано, что климатические изменения рассмотренных масштабов вызываются естественными причинами. Основными причинами климатических изменений являются естественные внешние факторы - колебания общего количества энергии Солнца вследствие изменений расстояния до него от Земли, а также солнечной активности. Повышение концентрации в атмосфере парниковых газов антропогенного происхождения в изменениях

\footnotetext{
${ }^{10}$ http://www.vestnik.com/issues/98/1013/win/moldav.htm.

${ }^{11} \mathrm{https} / /$ newizv.ru/comment/aleksandr-gorodnitskiy/10-02-2017/251901konec-mifa-o-globalnom-poteplenii
} 
климата Земли играет дополнительную роль. Интересно, что на основании параллельных измерений в Антарктиде было установлено, что при сокращении ледового покрова в Гренландии в противофазе увеличивается ледяной покров Антарктиды, так что ожидать всемирного потопа не надо. Антарктида не тает, а в ней $90 \%$ льда.

За последние годы число ученых, отвергающих решающее значение «парниковой теории» в объяснении климатических изменений, заметно увеличилось.

Мы посчитали необходимым изложить альтернативное мнение специалистов по климату относительно «теории глобального катастрофического потепления, обусловленного парниковыми газами», поскольку именно эта теория, популяризованная нобелевским лауреатом А. Гором, поддерживается многими получившими крупные гранты влиятельными учеными, а также активистами, включая такого нобелевского лауреата, как Грета Тунберг. В нашей стране она поддерживается руководителями Росатома [19] и солидарными с ними учеными в обоснование замены вредной тепловой энергетики.

Если бы все-таки потепление и происходило именно из-за накопления техногенного $\mathrm{CO}_{2}$ в атмосфере, Россия все равно не спасет человечество от тепловой катастрофы даже при максимальном сокращении традиционных источников тепловой энергии, замененных атомной энергией. Добываемые газ и нефть при этом в огромных количествах продаются для сжигания тем странам, которые считают после Чернобыльской и Японской атомных катастроф уровень опасности от АЭС для населения своих стран слишком высоким. Россия ту же Германию обеспечивает газом и нефтью, спасая от возможных последствий атомной катастрофы. Отметим также, что во всем мире, особенно в США и Китае, продолжают сжигать огромные объемы угля в электротепловых станциях, в котельных и в металлургии, а число автомашин во всем мире растет, и нефть сжигается в возрастающих количествах.

Мы подробно обсудили выше опасность для биосферы от производства плутония на АЭС. Эта опасность для России становится особенно высокой в связи с доставкой в хранилище под Красноярском ОЯТ не только от своих реакторов, но и от построенных и строящихся Росатомом за рубежом с целью последующей переработки ОЯТ для получения МОКС-топлива для тепловых и быстрых реакторов с высоким содержанием в топливе плутония, переработка которого уже начала производиться на ГХК для реактора БН-800 Белоярской АЭС.

Однако атомная энергетика в простом варианте сохранения установленной мощности с заменой реакторов первых поколений более надежными и при строительстве атомных ледоколов и танкеров без замыкания ядерного топливного цикла с переработкой большого количества ядерного топлива, без возвращения ОЯТ зарубежных реакторов, безопасна для всей биосферы и особенно для жителей нашей страны [34], ее и надо продолжать.

Отметим в конце этого раздела, что помимо риска для экологии существует риск для экономики: при строительстве иностранных АЭС в кредит от России с надеждой возместить расходы через 15-20 лет после строительства АЭС за счет продажи электроэнергии возможность потерять все велика, поскольку, случись в любом месте мира атомная катастрофа с выбросом радиоактивности во внешнюю среду, мировое сообщество призовет закрыть всю атомную энергетику. И придется либо ее закрыть, либо стать изгоем, умножив санкции, и при этом наверняка потерять все построенное за рубежом.

\section{Энергетика мира и Аоля в ней Фтомной энергии и ВИЭ}

В мировой энергетике атомная начала интенсивно развиваться с 1970-х годов. Комиссия по экономии энергии и энергоресурсов (Conservation Commission) мировой энергетической конференции (МИРЭК) в 1978 году подготовила доклад, основанный на результатах совместных исследований ряда национальных компаний и организаций Запада с привлечением ведущих экспертов разных стран из обобщенных этой Комиссией. Перевод и издание этого обширного доклада (256 с.) на русском языке с предисловием Почетного вице-председателя исполкома МИРЕК академика М.А. Стыриковича был осуществлен в СССР в 1980 году [16]. Развитие атомной энергетики было объявлено приоритетным. Доля атомной энергетики в производстве электроэнергии в 1975 году была около 4\%. Большинство прогнозов электропотребления исходило из того, что основная доля в обеспечении электроэнергией будет покрываться за счет атомной энергии. Доля электроэнергии, вырабатываемой в мире на базе атомной энергии, могло составить 45\% к 2000 году и 60-65\% - к 2020 году, а значения установленной мощности АЭС в мире составят к 2020 году 5000 ГВт, из этого количества 2225 ГВт будет установлено в странах-членах ОЭСР, 1850 ГВт - в странах с плановой системой экономики (СССР и Восточная Европа), 925 ГВт - в развивающихся странах. Авторами доклада были изучены пять сценариев развития атомной энергетики. В докладе основным является вариант, в котором первоначально используются легководные реакторы с постепенным вводом в эксплуатацию реакторов-размножителей на быстрых нейтронах с временем удвоения топлива, равным 24 годам. Начало широкой эксплуатации реакторов-размножителей предполагалось в США в 1993 году, в Западной Европе - в 1987, в Японии - в 2000 и в СССР - в 1995 году. В этом сценарии атомная энергетика обес- 
печена ядерным топливом на долгие времена. По этому сценарию и двинулось развитие атомной энергетики. Такие грандиозные планы предусматривали к 2020 году 5000 ГВт ядерной энергии, объявленной самой безопасной и чистой. Но сейчас, в 2020 году, установленная мощность всех АЭС меньше 400 ГВт. А энергетический реактор-размножитель на быстрых нейтронах только один промышленный, на Белоярской АЭС мощностью 800 МВт (реактор БН-600 на Белоярской АЭС переведен в статус опытного, а в Китае с помощью России работает еще один - опытный на 600 МВт, все остальные в мире небольшие экспериментальные). Не была развита атомная энергетика в предполагаемых масштабах, поскольку не оказалась безопасной и чистой.

В США в 1979 году произошла ничтожная по своим последствиям, при сравнении с Чернобыльской, авария на Трехмильном острове с частичным расплавлением ядерного топлива и попаданием во внешнюю среду сравнительно небольшого количества радиоактивных продуктов. Большую аварию удалось предотвратить. Но сама возможность такой аварии, которая чуть не произошла, обозначила огромную опасность атомных реакторов. Решением президента Картера было прекращено уже начатое строительство 28 атомных реакторов того типа, на котором произошла авария. Начатое строительство другой части реакторов было завершено, но после 1979 года и до 2012 года ни одной лицензии на строительство АЭС в США не было выдано. Намеченное интенсивное развитие атомной энергетики в США было остановлено. Сейчас в США 94 реактора и строится всего 2. Средний возраст реакторов уже превысил 40 лет. Держится сейчас вся атомная энергетика США только благодаря продлению срока эксплуатации сверх заложенных в конструкторских проектах 30 лет, сначала до 45, затем до 60, а сейчас до 80 лет, что не делает атомную энергетику более безопасной, особенно с учетом все возрастающего количества весьма опасных радиоактивных отходов в переполненных хранилищах при АЭС. Построенное весьма дорогое централизованное хранилище радиоактивных отходов Yucca Mountain в США не удалось задействовать из-за невозможности гарантировать его безопасность в течение долгих столетий. В сентябре 2017 года Минэнерго США оценивало будущие затраты на реализацию проекта «Yucca Mountain» как 27,2 миллиарда долларов. Однако политическая поддержка возобновления финансирования «Yucca Mountain» отсутствует. Практически на каждой площадке АЭС в США организовано промежуточное сухое хранилище ОЯТ, в которых находится огромное количество весьма опасных радиоактивных продуктов ${ }^{12}$. Мы отметили ситуацию с облученным ядерным топливом в США, стране с наибольшим

${ }^{12}$ https://www.atomic-energy.ru/SMI/2019/04/25/94321. количеством атомных реакторов и наибольшим количеством ОЯТ, судьбу которого не удается решить несмотря на высокое финансирование. От переработки ядерного топлива в США отказались в связи с дороговизной получаемого из него топлива и большим количеством радиоактивных отходов, часть которых неизбежно попадает во внешнюю среду.

Огромную опасность переработки большого количества ядерного топлива для всей биосферы, особенно при переработке ОЯТ с высоким содержанием плутония для реакторов на быстрых нейтронах, мы отметили выше при обсуждении ситуации в России.

После Чернобыльской катастрофы решение прекратить использование АЭС принято в Германии, Италии, Швейцарии, Португалии, хотя у них нет природных запасов нефти и газа. Этим они исключают атомные аварии для народов своих стран. Проблемой для этих стран остается ликвидация ядерного наследия и необходимость финансирования этих работ. После Фукусимской катастрофы были остановлены все реакторы в Японии, и из 54 сейчас перезапущены только 10. В то же время после Чернобыля все реакторы, в том числе и Чернобыльского типа, продолжали работать, включая три оставшихся РБМК в Чернобыле.

С быстрыми реакторами для сжигания всего урана при замыкании ядерного топливного цикла дела в мире обстояли так. После ряда аварий при эксплуатации первых реакторов на быстрых нейтронах в Германии, Франции, США и Японии строительство промышленных реакторов-размножителей во всех странах, кроме России, было прекращено. В 2020 году работают только два реактора на быстрых нейтронах, это БН-800 на Белоярской АЭС и опытный БН-600, построенный Россией в Китае. Кроме того, предполагается установить на Белоярской АЭС еще два реактора на быстрых нейтронах. Для реакторов на быстрых нейтронах требуется топливо с более высоким содержанием в нем плутония (15-20\%), и для его получения были созданы комбинаты по выделению плутония из ОЯТ тепловых реакторов, самые большие в Англии и Франции. В мире на них было наработано 250 тонн реакторного плутония. Но из-за отсутствия реакторов на быстрых нейтронах все это топливо лежит мертвым грузом на комбинатах, поскольку использование этого плутония в реакторах на медленных нейтронах не только экономически неэффективно, но и опасно. Весьма незначительное количество его применяли некоторое время во Франции (на трети реакторах при третьей части загрузки в активную зону). Сейчас с этим плутонием неизвестно что делать. Попытка использовать этот плутоний в реакторах Японии оказалась неудачной и закончилась выплатой высокого штрафа компанией БНФЛ.

В мировом производстве электроэнергии доля атомной составляет $11 \%$, а в общем производстве энер- 
гии доля в два раза меньше. Как следует из многочисленных прогнозов (итоговый анализ этих прогнозов проведен А.М. Мастепановым [12]), в 2050 году доля атомной в мировом производстве энергии останется такой же: 5-7\%, а если исключить интенсивно развивающийся Китай, то эта доля уменьшится на треть.

Проф. Б.И. Нигматуллин, один из ведущих независимых аналитиков, долгое время проработавший в руководстве атомной промышленностью, провел обстоятельный анализ перспектив развития различных источников электроэнергии до 2050 года. Приведенная им оценка прогноза развития атомной энергетики практически совпадает с оценкой из Китая, которую он приводит. В базисном варианте, как следует из его анализа, мощность всех АЭС во всем мире увеличится от 383 в 2015 году до 456 ГВт в 2050 году и составит $6,6 \%$ всей энергетики в 2050 году; при этом, как это следует из прогноза китайских ученых, число станций Китая увеличится от 41 до 243. Отсюда следует, что если исключить Китай, во всем остальном мире мощность АЭС в 2015 году была $383-41=342$ ГВт, а в 2050-м она будет всего $456-246=210$ ГВт, то есть мощность всех АЭС без Китая уменышится на $38 \%$ (это с учетом закрытия АЭС, выработавших свой 60-летний срок) [17].

В 2020 году приоритетным является развитие другой, экологически чистой возобновляемой энергии Солнца и ветра, и в нее инвестируется на порядок больше средств. Атомная энергетика во всех странах держится только на значительном продлении времени работы реакторов сверх запроектированного, что безусловно увеличивает опасность их эксплуатации. Без этого продления атомная энергетика прекратила бы свое существование через 10 лет (средний возраст всех реакторов в мире превысил 30 проектных лет). Атомные реакторы не строят сейчас не только из-за их высокой потенциальной опасности, но и потому, что себестоимость производимой на них энергии уже несколько лет назад значительно выше, чем от других источников, что видно из приводимых ниже табл. 1 и 2.

Табл. 1

\section{Средняя себестоимость производства электроэнергии в долларах за 1 МВТ.ч для различных строящихся источников*}

\begin{tabular}{|l|l|l|l|}
\hline \multicolumn{1}{|c|}{ Ресурс } & \multicolumn{1}{|c|}{$\begin{array}{c}\mathbf{2 0 0 9} \\
\text { год }\end{array}$} & \multicolumn{1}{|c|}{$\begin{array}{c}\mathbf{2 0 1 4} \\
\text { год }\end{array}$} & \multicolumn{1}{c|}{$\begin{array}{c}\mathbf{2 0 1 7} \\
\text { год }\end{array}$} \\
\hline Ядерная энергетика & 110 & 115 & $\begin{array}{l}135 \\
(+22 \%)\end{array}$ \\
\hline $\begin{array}{l}\text { Газ, комбинированный } \\
\text { цикл }\end{array}$ & 75 & 65 & $\begin{array}{l}60 \\
(-20 \%)\end{array}$ \\
\hline Ветровая энергетика & 130 & 50 & $\begin{array}{l}40 \\
(-69 \%)\end{array}$ \\
\hline Солнечная энергетика & 350 & 80 & $\begin{array}{l}50 \\
(-86 \%)\end{array}$ \\
\hline
\end{tabular}

* По данным регулярно публикуемых отчетов аналитика М. Шнайдера (Mycle Shneider) ${ }^{13}$.

${ }^{13}$ https://www.worldnuclearreport.org/IMG/pdf/wnisr2018-v2-lr.pdf
Стоимость единичной мощности на больших промышленных ВИЭ уже давно значительно меньше, чем ядерная, даже с учетом непостоянства их работы. Приведенные в таблице цифры являются усредненными, и, поскольку основной вклад в производство энергии обеспечивают большие ВИЭ, включенные в единую сеть, то в тех странах, где ВИЭ получили развитие, средняя себестоимость определяется ими.

Без учета капитальных затрат себестоимость становится существенно меньше, но тем самым продлеваются сроки эксплуатации, что является очень опасным.

Кроме того, и время строительства АЭС намного больше (атомная - 8-10 лет; газовая комбинированного цикла - 0,5-1 год, солнечные и ветровые - 1-2 месяца), особенно при учете времени согласования сооружения атомных реакторов с администрацией и общественностью. Приводимые сейчас в отечественной научной литературе для оправдания необходимости развития атомной высокие оценки себестоимости ветровой и солнечной энергетики имеют десятилетнюю давность. Кроме того, высокую себестоимость имеют источники небольшой мощности, которые сейчас, наконец, все-таки начали производиться в России. Интересно, что и Росатом в этом участвует.

Табл. 2

Средняя стоимость энергетических ресурсов (\$ США/МВТ) ${ }^{14}$

\begin{tabular}{|l|c|c|}
\hline \multicolumn{1}{|c|}{ Ресурс } & \multicolumn{2}{|c|}{ Стоимость } \\
\cline { 2 - 3 } & Полная & $\begin{array}{c}\text { Без учета } \\
\text { капитальных } \\
\text { затрат }\end{array}$ \\
\hline $\begin{array}{l}\text { Солнечные } \\
\text { кристаллические } \\
\text { фотоэлектрические } \\
\text { системы }\end{array}$ & $31-42$ & \\
\hline $\begin{array}{l}\text { Солнечные } \\
\text { фотоэлектрические } \\
\text { панели }\end{array}$ & $28-38$ & \\
\hline Ветровая энергия & $26-54$ & \\
\hline Ядерная энергия & $129-198$ & 29 \\
\hline Уголь & $65-159$ & 41 \\
\hline $\begin{array}{l}\text { Комбинированный } \\
\text { газовый цикл }\end{array}$ & $44-73$ & 28 \\
\hline
\end{tabular}

Кроме Китая, Индии и России атомная энергетика с учетом указанных выше проблем постепенно свертывается. Во всем мире инвестиции в нее уже давно значительно ниже, чем в экологически чистые возобновляемые источники энергии, что видно в табл. 3

\footnotetext{
${ }^{14}$ LCOE-2021. https://www.lazard.com/perspective/levelized-cost-of-energy-and-levelized-cost-of-storage-2020/
} 
Инвестиции в мире в различные отрасли энергетики (источник: см. табл. 1)

\begin{tabular}{|l|c|c|c|}
\hline \multirow{2}{*}{$\begin{array}{l}\text { Отрасль } \\
\text { энергетики }\end{array}$} & \multicolumn{3}{|c|}{ Млрд \$ в год } \\
\cline { 2 - 4 } & $\mathbf{2 0 0 9}$ год & $\mathbf{2 0 1 4}$ год & $\mathbf{2 0 1 7}$ год \\
\hline Ядерная & 40 & 25 & 20 \\
\hline Ветровая & 80 & 110 & 110 \\
\hline Солнечная & 60 & 150 & 160 \\
\hline
\end{tabular}

Поскольку инвесторы склонны делать вложения по тем направлениям, которые могут обеспечить отдачу от вложений при наименьших затратах через короткий промежуток времени, то естественно, желание вкладываться в атомную энергетику с ее высокой себестоимостью отсутствует. Здесь существенным является длительное время строительства, которое для АЭС значительно больше (8-10 лет), чем для сооружения электростанции на газе, которое составляет полгода-год, и еще скорее при сооружении энергоблоков, использующих энергию Солнца. Время строительства атомных станций может еще затянуться после возможных крупных аварий на любой из них, последствия которых приостанавливают или отменяют вообще уже начатое строительство. Поэтому риск потерять деньги, вложенные в строительство АЭС, весьма велик. Как отмечено выше, после сравнительно небольшой аварии на АЭС в США было прекращено уже начатое строительство 28 реакторов. После Чернобыльской катастрофы во многих странах мира было прекращено строительство многих АЭС. В результате развернутого антиядерного движения и в России было остановлено строительство АЭС в Горьком и Ростове, в Крыму, Башкирии, Татарстане.

Атомные электростанции сейчас наиболее интенсивно строят Китай и Россия, причем не только в своих странах. Китай не обладает большими запасами нефти и газа, уголь слишком загрязняет биосферу, а гидроэнергия не только на больших реках, но и на малых почти исчерпана. Поэтому при осуществлении программы интенсивного экономического роста с обеспечением в максимально короткие сроки более высокого уровня жизни для своих граждан, Китай вынужден использовать опасную атомную энергию. Интересно, что стоимость строительства китайских АЭС и сроки строительства в два раза меньше российских. Но приоритетом и для Китая является строительство электростанций с использованием энергии Солнца и ветра, инвестиции в них значительно выше, чем в атомную энергетику, производство электроэнергии на ветре превышает с 2011 года производства на АЭС, что видно из табл. 4.
Произведенная за год энергия (ТВт·ч) на АЭС и ВИЭ в Китае

\begin{tabular}{|l|c|c|c|}
\hline $\begin{array}{l}\text { Отрасль } \\
\text { энергетики }\end{array}$ & $\mathbf{2 0 0 9}$ год & $\mathbf{2 0 1 4}$ год & $\mathbf{2 0 1 7}$ год \\
\hline Ядерная & 66 & 124 & 233 \\
\hline Ветровая & 28 & 156 & 286 \\
\hline Солнечная & 4 & 30 & 108 \\
\hline
\end{tabular}

Строительство возобновляемых источников энергии является приоритетным сейчас во всем мире по самым разным прогнозам. Итоговые результаты этих прогнозов проанализированы и приведены в работе [12].

\section{Закиючение}

Россия обладает самыми большими запасами органического топлива. Особенно велики запасы природного газа. Для нашей северной страны весьма важным является то, что только на ТЭС при сжигании газа и угля получается, причем в количестве не меньшем, чем полезная электрическая энергия, дополнительная тепловая энергия. Поэтому заменить их на атомные, не производящие парниковых газов, но производящие в огромном количестве радиоактивные продукты, более опасные для биосферы и здоровья людей, означает еще и сократить в стране потребление парового отопления и горячей воды.

Неиспользованные гидроресурсы в России одни из самых больших. Во всем мире в последнее десятилетие получили исключительно высокое развитие нетрадиционные экологически чистые возобновляемые источники энергии, которые практически совсем не используются в России, хотя энергетические резервы энергии ветра, геотермальной энергии и приливной энергии моря самые большие. Но благодаря мощному лоббированию представителями всего атомного сектора, частью которого является мирная атомная энергетика, именно эта энергетика избрана для обеспечения энергетической безопасности России на долгие времена. Россия строит многие атомные реакторы не только у себя, но и за рубежом при условии поставки для них ЯТ с последующим возвратом в Россию ОЯТ для переработки в опасное МОКС-топливо. Стратегия Росатома развития АЭ с замыканием ядерного топливного цикла при использовании реакторов на быстрых нейтронах увеличивает опасность для биосферы многократно из-за более высокого содержания в ЯТ плутония и необходимости частой переработки ОЯТ, которую предполагают проводить рядом с реактором. Высокозатратный атомный путь развития энергетики страны является опасным, и не только для России, а ее лишает возможности финансировать и потому со- 
вершенствовать и развивать все другие области энергетики, которые сейчас осваиваются во всем мире, и это при том, что запасы традиционных источников самые большие, а резервы альтернативных возобновляемых экологически чистых источников энергии неисчерпаемы.

Аргументы, которыми пытаются обосновать необходимость инвестиций в развитие весьма опасной и дорогой атомной энергетики, являются при анализе недостаточными.

Безусловно, и при создании ториевых реакторов атомная энергетика становится значительно более безопасной при текущем использовании. Но при широкомасштабном ее развитии в варианте основного производителя энергии создает в итоге такое же количество радиоактивных продуктов при делении, как и существующая энергетика. Да и, по правде говоря, уран-233 и особенно уран-232 не такие безопасные, как уран-238. Поэтому большая ядерная энергетика и в уран-ториевом варианте тоже не является безопасной для человечества и биосферы.

А вот использование жидкосолевых уран-ториевых реакторов для ледоколов, больших контейнерных и подводных судов, а также создание небольших мегаваттных автономных на 30 лет источников энергии для труднодоступных мест по побережью Северного Ледовитого океана, в Восточной Сибири или в Антарктиде было бы вполне уместно, с окончательной консервацией радиоактивных продуктов в застывшей и рассредоточенной солевой композиции [10]. Для освоения космоса такие источники были бы тоже полезны. 1000 таких мегаваттных источников создадут в итоге такое же количество радиоактивных продуктов, как и одна АЭС мощностью 1 ГВт, причем на порядки более безопасных для длительного хранения из-за отсутствия плутония и актинидов.

Может быть, в России, как уже почти во всех странах, возьмутся всерьез использовать самые большие на Земле ресурсы ВОЗОБНОВЛЯЕМОЙ ЭНЕРГИИ? Резервы России самые большие и по энергии ветра, и по приливной энергии океана, и по геотермальной энергии.

Благоприятные перспективы использования солнечной энергии есть на Северном Кавказе, в Нижнем Поволжье и в Забайкалье, то есть в районах, где в году много ясных солнечных дней. Самые ветряные районы расположены вдоль береговой линии Северного Ледовитого океана и в Калининградской области. На Кольском полуострове, в Кислой губе, есть небольшая электростанция, работающая на энергии морских приливов и отливов, начатое же давно строительство большой Мезенской приливной станции из-за от- сутствия финансирования практически прекращено. Большие возможности для строительства такого рода электрических станций имеются на побережье Охотского моря, где приливы достигают 18 метров.

Источники геотермальной энергии есть в сейсмически активных зонах Земли. В России это Камчатка (в долине гейзеров работает только одна небольшая электростанция) и одна на Курильских островах.

Но основное внимание и средства направлены на атомную энергетику, альтернативы которой, как заявляют руководители атомного ведомства, - НЕТ.

И это заявляется, когда в 2017 году 157 ГВт возобновляемых источников энергии, добавленных к мировым электрическим сетям, по сравнению с 143 ГВТ, добавленными в предыдущем году, представляют собой самый большой рост в истории. Увеличение составило более $61 \%$ чистого прироста мировых генерирующих мощностей. Ветровая энергетика добавила 52 ГВт и солнечная - рекордные 97 ГВт. Эти цифры можно сравнить с увеличением на 3,3 ГВт для ядерной энергетики в том же году ${ }^{14}$.

Уровень ВИЭ в России в 2016 году по сравнению со среднемировым $(13,6 \%)$ - только $1 \%$, в том числе 0,6\% - биомасса, 0,3\% - малые ГЭС, и всего $\mathbf{0 , 1 \%}-$ ветряная и солнечная электроэнергетика и геотермальные источники. И это при том, что страна обладает огромнейшими запасами чистой для биосферы и людей энергии.

Правда, энергия, получаемая от Солнца и ветра, непостоянна и мелкомасштабна по сравнению с атомной. Но этот недостаток во многом нивелируется при включении их в единую электрическую сеть, что осуществляется, например, в США, Германии и Китае. Большие надежды при развитии энергетики с использованием ветра и Солнца возлагаются на создание дешевых аккумуляторов большой емкости, тогда и отдельные источники этой энергетики могли бы работать непрерывно.

Резервы ВИЭ России настолько велики, что ими без ущерба для себя можно и поделиться. Вдобавок к отмеченным выше источникам огромны запасы приливной энергетики у океанских берегов России. Так, более 30 лет назад в Ленинградском политехническом институте (ныне Политехнический университет им. Петра Великого) был создан эскизный проект Пенжинской приливной электростанции на Охотском море мощностью 90 млрд Ватт (среднесуточная 40 ГВт). Сейчас этот проект реанимирован ${ }^{15}$. Напоминаем, что 40 ГВт - это мощность, превышающая мощность всех атомных электростанций России, которая сейчас равна 30 ГВт.

\footnotetext{
${ }^{15}$ https://www.rbc.ru/business/12/07/2021/60ec4ab99a7947fca921f1eb
} 


\section{Аитература}

\section{Список русскоязычной литературы}

1. Александров АП и соавт. Атомная наука и техника в СССР. М.: Атомиздат; 1977.

2. Александров ВВ, Стенчиков ГИ. Об одном вычислительном эксперименте, моделирующем климатические последствия ядерной войны. Журн вычисл мат физ. 1984;24(1):140-4.

3. Адамов ЕО, Большов ЛА, Ганев ИХ и соавт. Белая книга ядерной энергетики. М.: Изд-во ГУП НИКИЭТ; 2001.

4. Булдаков ЛА. Радиоактивные вещества и человек. М.: Энергоатомиздат; 1990.

5. Василенко ИЯ. Токсикология продуктов ядерного деления. М.: Медицина; 1999.

6. Действие ядерного оружия. М.: Воениздат; 1965. http://elib.biblioatom.ru/text/deystvieyadernogo-oruzhiya_1965/go,0/

7. Колобашкин ВМ и соавт. Радиационные характеристики облученного ядерного топлива. М.: Энергоатомиздат; 1983.

8. Кондратьев КЯ, Крапивин ВФ, Савиных ВП. Перспективы развития цивилизации: многомерный анализ. М.: Логос; 2003.

9. Криволуцкий ДА и соавт. Действие ионизирующей радиации на биогеоценоз. М.: Гидрометеоиздат; 1967.

10. Кузякин ЮИ, Яковлев РМ. Транспортная жидкосолевая реакторная установка. В кн.: Сборник докладов научно-технической конференции «Корабельная ядерная энергетика - взгляд в XXI век». Нижний Новгород: ОКБМ; 2001.

11. Магилл И, Хэмилтон Д, Лютценкирхен К, Туфан М, Тамборини Г, Вагнер В, Берту В, фон Цвайдорф А. Последствия события радиологического рассеивания с ядерными и радиоактивными источниками. Наука и всеобщая безопасность. 2007;15(2):12-21. https://scienceandglobalsecurity.org/ru/archive/sgsr15magill.pdf.

12. Мастепанов АМ. Энергетический переход как генеральное направление энергетики будущего. Экол вестн России; 2020;(1)10-5;(2):12-9.

13. Медоуз Д, Рандерс Й, Медоуз Д. Пределы роста. 30 лет спустя. М.: Академкнига; 2008.

14. Моисеев НН. Экология человечества глазами математика. М.: Молодая гвардия; 1988.

15. Моисеев НН, Александров ВВ, Тарко АМ. Человек и биосфера. Опыт системного анализа и эксперименты с моделями. М.: Наука; 1985.

16. Старшинов ЮИ, ред. Мировая энергетика. Прогноз развития до 2020 года. М.: Энергия; 1980.
17. Нигматуллин БИ. Прогноз мирового электропроизводства на АЭС на период до 2050 г. Атомная стратегия. 2017;(3). http://www. proatom.ru/modules.php?name $=$ News \&file $=$ artic le\&sid $=7390$.

18. Нигматуллин РИ. Во власти океана. Наука в России. 2010;(4):54-62.

19. Решетников ЕА. Светлое будущее наступит не от белых ночей, а от атомных станций. Атомная стратегия. 2004;8(13):4-6.

20. Римский-Корсаков АА. Две аварии. Атомная стратегия. 2011;(53):20-5.

21. Розенберг ГС. Глобальные модели динамики биосферы. Биосфера. 2017;9(2):107-22.

22. Рылов МИ, Тихонов МИ. В мире дозообразующих нуклидов. СПб.: Межотраслевой экспертно-сертификационный центр ядерной и радиационной безопасности; 2011.

23. Сергеев ЮН, Кулеш ВП. Проблемы цикличного и стационарного развития цивилизации в глобальных моделях. Биосфера. 2017;9:1347.

24. Суглобов ДН, Яковлев РМ, Мясоедов БФ. Торий-урановый топливный цикл для тепло- и электроэнергетики. Радиохимия, 2007;49(5):385-92.

25. Тихонов МИ, Муратов ОЭ. Катастрофы как источник потери устойчивости национальных государств. В кн. Проблемы риска в техногенной и социальной сферах. СПб.: Изд-во СПбГПУ; 2007. С. 119-30.

26. Форрестер Д. Мировая динамика. М.: Наука; 1978.

27. Фролов ИЕ, Гудкович ЗМ, Карклин ВП, Ковалев ЕГ, Смоляницкий ВМ. Научные исследования в Арктике. Т. 2. Климатические изменения ледяного покрова морей Евразийского шельфа. СПб.: Наука; 2007.

28. Фролов ИЕ, Гудкович ЗМ, Карклин ВП, Ковалев ЕГ, Смоляницкий ВМ. Климатические изменения ледовых условий в арктических морях Евразийского шельфа. Проблемы Арктики и Антарктики. 2007;75:149-60.

29. Яблоков АВ, Нестеренко ВБ, Нестеренко АВ. Чернобыль: последствия катастрофы для человека и природы. СПб.: Наука; 2011.

30. Яблоков АВ. Миф о незначительности последствий Чернобыльской катастрофы. М.: Центр экологической политики России; 2001.

31. Яковлев РМ. О реакторах нового поколения. Атомная стратегия. 2005;(4):20-1. 
32. Яковлев РМ, Данилевич ЯБ, Игнатьев МБ, Суглобов ДН. Атомная энергетика без плутония и Чернобыля. Мир и согласие. 2008;2:58-64.

33. Яковлев РМ, Петров ЭЛ, Тихонов МН, Муратов ОЭ. Решение проблем ядерной энергетики в стратегии уран-ториевого топливного цикла. Атомная стратегия. 2007;(5). http://www. proatom.ru/modules.php?name $=$ News $\&$ file $=$ artic le\&sid $=970$

34. Яковлев РМ, Обухова ИА. Оценка перспектив применения альтернативных моделей реакторов в ядерной энергетике. Информационные системы и технологии. 2018;10:3-13.

35. Яковлев РМ, Обухова ИА. Ситуация с нераспространением ядерного оружия и проблемы развития атомной энергетики. Информационные системы и технологии. 2019;11:153-69.

36. Яковлев РМ, Обухова ИА. На пути к безопасной атомной энергетике. Биосфера. 2017;9(2):123-35.

37. Яковлев РМ, Обухова ИА. О нераспространении ядерного оружия и проблемах развития атомной энергетики России. Экологический вестник России, 2020:(1):32-6.

\section{Общий список литературы/Reference List}

1. Aleksandrov AP et al. Atomnaya Nauka i Tehnika v SSSR. Moscow: Atomzdat; 1977. (In Russ.)

2. Aleksandrov VV, Stenchikov GI. [On a computational experiment imitating the climatic consequences of a nuclear war]. Zhurnal Vychilitelnoy Matematiki i Matematicheskoy Fiziki. 1984;24(1):140-4. (In Russ.)

3. Adamov YeO. et al. Belaya Kniga Yadernoy Energetiki. Moscow: GUP NIKIET; 2001. (In Russ.)

4. Buldakov LA. Radioaktivnye Veschestva i Chelovek. Moscow: Energoatomizdat; 1990. (In Russ.)

5. Vasilenko IJa. Toksikologiya Produktov Yadernogo Deleniya. Moscow: Meditsyna; 1999. (In Russ.)

6. Galsstone S. The Effects of Nuclear Weapons. Washington: United States Atomic Energy Commission; 1962.

7. Kolobashkin VM et al. Radiatsionnye Kharakteristiki Obluchionnogo Yadernogo Topliva. Moscow: Energoatomizdat; 1983. (In Russ.)

8. Kondratyev KJa, Krapivin VF, Savinykh VP. Perspektivy Razvitiya Tsivilizatsii: Mnogomernyi Analiz. Moscow: Logos, 2003. (In Russ.)

9. Krivolutskiy DA et al. Deystviye Ioniziruyushchey Radiatsii na Biogeotsenoz. Moscow: Gidrometeoizdat; 1967. (In Russ.)

10. Kuziakin JuI, Jakovlev RM. [Vehicular molten salt reactor unit]. In: Korabelnaya Yadernaya En- ergetika - Vzgliad v XXI vek. Nizhnij Novgorod: OKBM; 2001. (In Russ.)

11. Magill J, Hamilton D, Lutzenkirchen K, Tufan M, Tamborini G, Wagner W, Berthou V, von Zweidorf A. Consequences of a radiological dispersal event with nuclear and radioactive sources. Sci Glob Secur. 2007;15:107-32.

12. Mastepanov AM. [Energy transition as the principal trend of the future energetics]. Ekologicheskiy Vestnik RossiiRossii; 2020; (1):10-5; (2):12-9. (In Russ.)

13. Meadows DH, Meadows DL, Randers J. The Limits of Growth. Washington DC: Potomac Assoc.; 1972.

14. Moiseev NN. Ekologiya Chelovechestva Glazami Matematika. Moscow: Molodaya Gvardiya; 1988. (In Russ.)

15. Moiseev NN, Aleksandrov VV, Tarko AM. Chelovek i Biosfera. Opyt Sistemnogo Analiza i Eksperimenty s Modeliami. Moscow: Nauka; 1985. (In Russ.)

16. World Energy Demand: Full Report to the Conservation Commission of the World Energy Conference. IPC Sci. \& Technol. Publ.; 1978.

17. Nigmatullin BI. [Forecast for world production of electric power by nuclear plants up to 2050]. Atomnaya Strategiya. 2017:(3). (In Russ.) http:// www.proatom.ru/modules.php?name=News\&file $=$ article $\&$ sid $=7390$.

18. Nigmatullin RI. [At Ocean's mercy]. Nauka v Rossii. 2010;4:54-62. (In Russ.)

19. Reshetnikov YeA. [The bold future will come not out of the white nights but due to nuclear power]. Atomnaya Strategiya. 2004;8(13):4-6. (In Russ.)

20. Rimskiy-Korsakov AA. [Two accidents]. Atomnaya Strategiya. 2011;(53):20-5. (In Russ.)

21. Rozenberg GS. [Global models of the dynamics of the biosphere]. Biosfera. 2017;9(2):107-22. (In Russ.)

22. Rylov MI, Tikhonov MI. V Mire Dozoobrazuyuschikh Nuklidov. Saint Petersburg. Mezhotraslevoy Eeksperktno-Sertifikatsionnyi Tsentr Yadernoy i Radiatsionnoy Bezopasnosti; 2011. (In Russ.)

23. Sergeev JuN, Kulesh VP. [Cyclic and stationary modes of the development of civilization in global models]. Biosfera. 2017;9:13-47. (In Russ.)

24. Suglobov DN, Yakovlev RM, Miasoyedov BF. [Thorium-uranium fuel cycle for thermo- and electro-energetics]. Radiokhimiya, 2007;49(5):385-92. (In Russ.)

25. Tikhonov MI, Muratov OE. [Catastrophes as a cause of the loss of stability of nations]. In: Problemy Riska v Tekhnogennoy i Sotsialnoy Sferakh. Saint Petersburg, Izdatelstvo SPbGPU; 2007. P. 119-30. (In Russ.) 
26. Forrester JW. World Dynamic. Wright-Allen Press; 1973.

27. Frolov IE, Gudkovich ZM, Karklin VP, Kovalev YeG, Smolianitskiy VM. Nauchnye Issledovaniya v Arktike. T. 2. Klimaticheskiye Izmeneniya Ledianogo Pokrova Morey Yevraziyskogo Shelfa. Saint Petersburg: Nauka, 2007. (In Russ.)

28. Frolov IE, Gudkovich ZM, Karklin VP, Kovalev YeG, Smolianickiy VM. [Climatic changes in the glacial conditions in the Arctic seas of the Eurasian shelf]. Problemy Arktiki i Antarktiki. 2007;75:149-60. (In Russ.)

29. Yablokov AV, Nesterenko VB, Nesterenko AV. Chernobyl: Posledstviya Katastrofy dlia Cheloveka i Prirody. Saint Petersburg: Nauka; 2011. (In Russ.)

30. Yablokov AV. Mif o Neznachitelnosti Posledstviy Chernobylskoy Katastrofy. Moscow; Tsentr Ekologicheskoy Politiki Rossii; 2001. (In Russ.)

31. Yakovlev RM. [On new-generation reactors]. Atomnaya Strategiy. 2005;(4):20-1. (In Russ.)

32. Yakovlev RM, Danilevich YaB, Ignatyev MB, Suglobov DN. [Nuclear Energetics without Plutonium and Cernobyl]. Moscow: Mir i Soglasiye,2008;2:58-64. (In Russ.)

33. Yakovlev RM, Petrov EL, Tikhonov MN, Muratov OE. [A solution of the problems of nuclear energetics is in the Thorium-Plutonium cycle strategy]. Atomnaya
Strategiya. 2007;(5) http:/www.proatom.ru/modules.php? name $=$ News\&file $=$ article $\&$ sid $=970$ (In Russ.)

34. Yakovlev RM, Obukhova IA. [An estimate of the prospects for using alternative models of reactors in nuclear energetics]. Informatsionnye Sistemy i Tekhnologii. 2018;10(2):3-13. (In Russ.)

35. Yakovlev RM, Obukhova IA. [The current state of affairs concerning nuclear weapons non-proliferation and the problems of development of the nuclear energetics]. Informatsionnye Sistemy i Tekhnologii. 2019;11:153-69. (In Russ.)

36. Yakovlev RM, Obukhova IA. [Towards safe nuclear energy]. Biosfera. 2017;9(2):123-35. (In Russ.)

37. Yakovlev RM, Obukhova IA. [On nuclear weapons non-proliferation and the problems of development of nuclear energetics]. Ekologicheskiy Vestrik Rossii. 2020:(1):32-36. (In Russ.)

38. Sagan S. Nuclear war and climatic catastrophe: Some policy implications. Foreign Affairs. 1983;62(2):257-92.

39. Proskuryakova L. Foresight for the 'energy' priority of the Russian Science and Technology Strategy. Energy Strategy Reviews. 2019;26:100378. doi: 10.1016/j.esr.2019.100378.

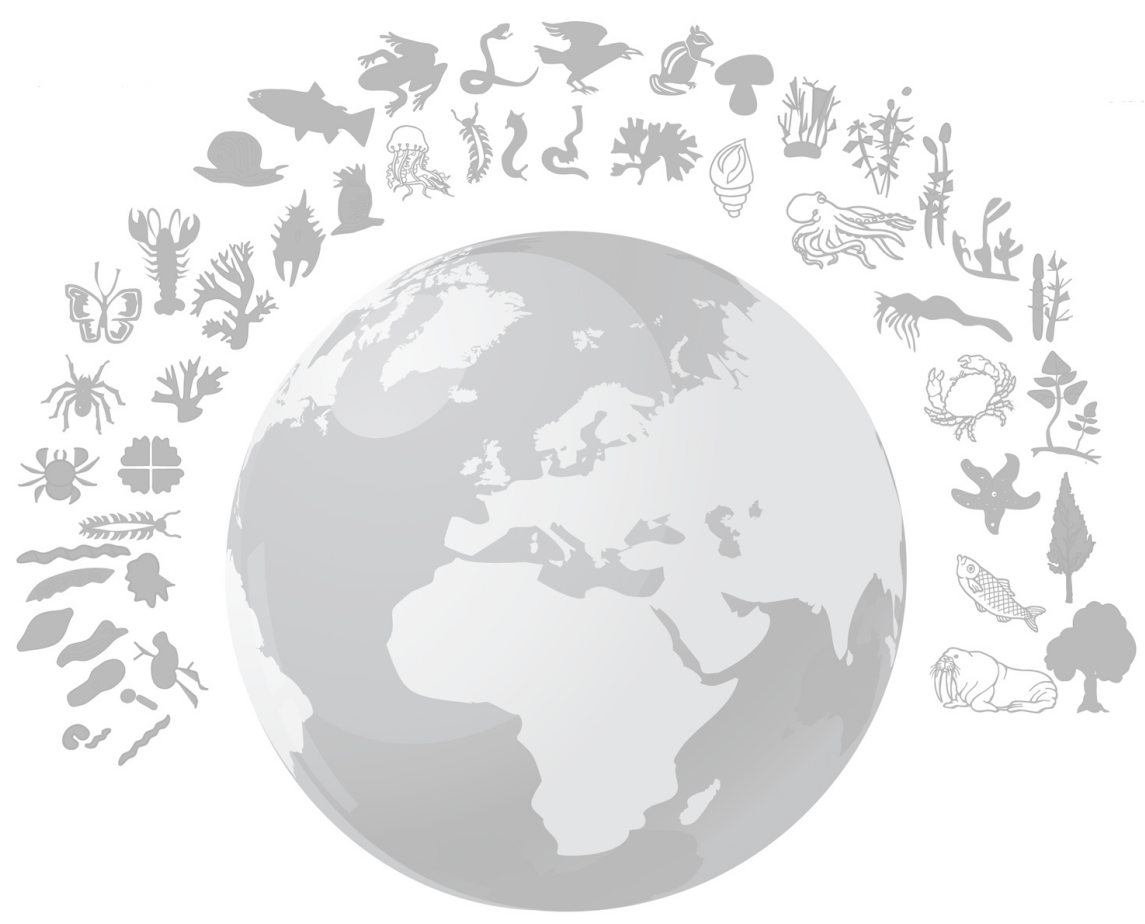

